\title{
Modelling, Transient Simulation and Economic Analysis of Solar Thermal Based Air Conditioning System in Gujarat
}

\author{
Ganesh Utham1, Sagarkumar M. Agravat', Bela Jani'3 , Jignasha Bhutka4 \\ ${ }^{1}$ School of Mechanical and Building Science, VIT University, Vellore, India \\ ${ }^{2}$ Solar R\&D Projects, Gujarat Energy Research \& Management Institute (GERMI), Gandhinagar, India \\ ${ }^{3}$ Gujarat State Electricity Corporation Limited (GSECL), Vadodara, India \\ ${ }^{4}$ Gujarat Energy Research \& Management Institute (GERMI), Gandhinagar, India \\ Email: utham_ganesh@yahoo.co.in, sagar.a@germi.res.in, belajanigsecl@gmail.com,jignasha.b@germi.res.in
}

Received 23 May 2016; accepted 28 August 2016; published 31 August 2016

Copyright (C) 2016 by authors and Scientific Research Publishing Inc.

This work is licensed under the Creative Commons Attribution International License (CC BY).

http://creativecommons.org/licenses/by/4.0/

(c) () Open Access

\begin{abstract}
Commercial building sector accounts for $8 \%$ of the total electricity consumption in India. Cooling activities (HVAC) in commercial buildings consume $55 \%$ of the total energy utilized. Consequently, $\mathrm{CO}_{2}$ emissions from conventional buildings in India were estimated to be 98 metric tonnes of $\mathrm{CO}_{2}$ per million $\mathrm{ft}^{2}$ in 2014 . Solar thermal air conditioning can be the solution to these demands and can contribute to about $15 \%$ to $20 \%$ of India's total oil consumption thereby reducing the dependence on fossil fuels. Hence, the main objective of the work is to model and simulate a solar absorption cooling system for GERMI office building located in Gandhinagar, Gujarat, India, using the transient simulation software 'TRNSYS'. Cooling load estimation and comfort conditions required for the building were determined based on ASHRAE standards. Evacuated tube collectors were selected because of its market availability, ease of manufacturing and proven technology. Single effect absorption chiller was used because of its commercial availability. The effects of storage tank volume, collector area and collector slope were also investigated for parametric optimization. The results of the simulation and parametric analysis are analyzed and presented in the paper.
\end{abstract}

\section{Keywords}

Solar Air Conditioning, Evacuated Tube Collectors (ETC), TRNSYS, Simulation, Single Effect Absorption Chiller, Parametric Analysis, India

\section{Introduction}

Air conditioners account for $45 \%$ of the total energy consumption in the residential and commercial building

How to cite this paper: Utham, G., Agravat, S.M., Jani, B. and Bhutka, J. (2016) Modelling, Transient Simulation and Economic Analysis of Solar Thermal Based Air Conditioning System in Gujarat. Smart Grid and Renewable Energy, 7, $233-246$. http://dx.doi.org/10.4236/sgre.2016.78018 
sector in India [1]. At the moment, 73\% of India's energy demand is predominantly met by fossil fuels. Fossil fuel based power plants has substantial negative impacts associated with them in terms of public health as well as a contribution to global warming. The high electricity demand also takes a toll on the national grid and results in the blackout. Hence, it is sensible to shift towards solar energy solutions to meet these demands.

India is blessed with excellent solar radiation with an annual average global solar irradiance of $4-7 \mathrm{kWh} / \mathrm{m}^{2} /$ day which can be harnessed through heat and electricity. The fact that demands for cooling in summer matches with solar radiation availability has kindled the interests of many researchers to utilize solar energy. One way of using solar radiation is to convert it into thermal energy through thermal solar collectors and use it to drive thermally driven cooling systems such as vapor absorption system. A single-effect lithium bromide-water ( $\mathrm{LiBr}-$ $\mathrm{H}_{2} \mathrm{O}$ ) absorption cooling system operates at a generator temperature in the range of $70^{\circ} \mathrm{C}$ to $95^{\circ} \mathrm{C}$ and requires water as cooling fluid in the absorber and the condenser [2].

A number of experimental and simulation studies [3]-[9] have been carried out in the field of solar absorption cooling systems to promote this technology. Assilzadeh et al. [3] worked on the simulation and optimization of a $\mathrm{LiBr}$ solar absorption cooling system with evacuated tube collectors for Malaysia weather condition using TRNSYS software. The authors suggested that a $0.8 \mathrm{~m}^{3}$ hot water storage tank essential to achieve continuous operation and the optimum design for a $3.5 \mathrm{~kW}$ (1 refrigeration ton) system consisted of $35 \mathrm{~m}^{2}$ evacuated tubes solar collector titled at $20^{\circ}$. Florides et al. [4] presented the modelling and simulation of an absorption solar cooling system for Cyprus. The results showed that a $15 \mathrm{~m}^{2}$ compound parabolic collector tilted at $30^{\circ}$ from the horizontal and a 600-L hot water storage tank was the optimized system. The collector area was determined by performing the life cycle analysis of the system. The system operated with maximum performance when the auxiliary boiler thermostat was set at $87^{\circ} \mathrm{C}$. Kim [5] cited that (Lokurlu and Muller, 2005) reported a system installed in Turkey, which consisted of a steam-driven double-effect absorption machine, a solar parabolic trough collector and a backup steam boiler. The trough collector with an $180 \mathrm{~m}^{2}$ aperture area heated pressurized water up to $180^{\circ} \mathrm{C}$ and this water in turn generated $144^{\circ} \mathrm{C}$ steam (4 bar) for a $110 \mathrm{~kW}$ double effect $\mathrm{LiBr}-\mathrm{H}_{2} \mathrm{O}$ chiller. Martinez et al. [6] simulated a hot-water-fired, double-effectLiBr- $\mathrm{H}_{2} \mathrm{O}$ absorption system using TRNSYS and also validated the model with experimental data. The model predicted $30 \%$ lower energy consumption as compared with experimental results. This difference was attributed to steady state modelling, which did not consider the transient performance. It was deduced that the simulation time steps should be lower than $1 \mathrm{~h}$. Ayompe et al. [7] modelled a forced circulation solar water heating system with flat plate and heat pipe-based ETCs for the climate conditions of Dublin, Ireland. Experimental study was carried out on both the systems. The comparison between modelled and measured values of heat gathered by the collector showed mean absolute error in the range of $7 \%$ to $19 \%$. By simulating a solar cooling system, Eicker and Pietruschka [8] showed that different collector areas $\left(2-4 \mathrm{~m}^{2} \mathrm{~kW} \mathrm{cool}{ }^{-1}\right)$ were required to reach a design solar fraction (80\%) depending on the characteristics of the building load and on the chosen control strategy. The model of the solar cooling system included a single-effect water-lithium bromide absorption chiller and a commercial evacuated tube solar collector $\left(\mathrm{a}_{0}=0.775, \mathrm{a}_{1}=1.476 \mathrm{~W} / \mathrm{m}^{2} / \mathrm{K}, \mathrm{a}_{2}=0.0075 \mathrm{~W} / \mathrm{m}^{2} / \mathrm{K}\right)$. Zambrano et al. [9] developed a dynamic solar cooling plant model. This model was validated with real data from a demonstration plant located in Seville (Spain), which had a flat-plate collector field of $151 \mathrm{~m}^{2}$ to drive a $35 \mathrm{~kW}$ single-effect water-lithium bromide absorption chiller. The storage tank volume was found to be $2.5 \mathrm{~m}^{3}$.

At present, only a few successfully installed solar thermal air conditioning systems installations is operational in India. The first such installation was in the year 2006 at Mamata Energy Plant located in Ahmadabad, Gujarat. The system consisted of a 25TR single effect Vapour absorption chiller integrated with evacuated tube collectors. The second system was designed and commissioned by Thermax, which was installed at the Solar Energy Centre in Gurgaon, Haryana, India. The $100 \mathrm{~kW}$ technology demonstration project was the first of its kind in the world which involved the use of triple effect absorption chiller integrated with solar parabolic concentrators. The company claimed to have made a technological breakthrough by delivering highest Coefficient Of Performance (COP) in the global markets today. The next major installation was at Kailash Cancer Hospital and Research Centre, Muni Seva Ashram located at Goraj, Gujarat. The hospital had installed 100 Scheffler concentrators with $12.5 \mathrm{~m}^{2}$ capacity each to meet the 100 TR cooling requirements.

Besides these demonstration projects, few simulation programs have been developed to evaluate the performance of solar cooling in India. Mittal et al. [10] simulated the performance evaluation of solar absorption cooling system of Bahal (Haryana). The performance of a $10.5 \mathrm{~kW}$ solar-driven lithium bromide absorption 
cooling system was investigated numerically. The authors concluded that increasing the hot water temperature decreases the absorber and solution heat exchanger surface area, while the dimensions of the other components remain approximately unchanged.

To summarize, many previous studies have been done to simulate solar absorption system worldwide. There is a shortage on the investigation of solar cooling system performance for Indian conditions. However, to the best of our knowledge, solar absorption cooling system has not yet been investigated for climatic conditions of Gujarat. Moreover, only a few studies have included the influence of parameters like ambient conditions and size of the storage tank, on the performance of the system. Hence, the paper presents the modelling and dynamic simulation of a solar assisted air conditioning system located in an office building using TRNSYS. The effects of storage tank volume, collector area and collector slope were also investigated and presented in this paper. Sensitivity analysis was carried out to optimize system parameters for performance enhancement.

\section{Materials and Methods2.1. Building Description}

The two-story building considered in this study is situated in Gandhinagar at $72.68^{\circ} \mathrm{E}$ longitude, and $23.22^{\circ} \mathrm{N}$ latitude in Gujarat, India at an elevation of about 81 meters above mean sea level. The dimensions of the building that are to be air conditioned are $65 \times 15 \times 4 \mathrm{~m}$ in size.

\subsection{Cooling Load Calculation}

Cooling load is the amount of heat energy that would need to be removed from a building space to maintain constant air temperature inside the premises. Cooling Load Temperature Difference method (CLTD) was adopted to determine the cooling load of the office building. We have used the standard method adopted by the American Society of Heating, Refrigerating, and Air-conditioning Engineers (ASHRAE) [11]. It takes into account both the external and internal loads. The external cooling load consists of the following: sensible loads through roofs, walls and conduction through a glass; Solar load through a glass and cooling load from partitions, ceilings and floors. Internal cooling loads consist of the following: heat gain from occupants, lighting and office equipment, appliances and infiltration and ventilation. The total load is the summation of external and internal load or both sensible and latent loads. By following the procedure for calculating space design cooling load by CLTD method, 25TR was the final cooling load of the building.

\subsection{Modelling in TRYNSYS Ver. 17}

Solar based absorption cooling system was modelled using TRNSYS 17 simulation program. A TRNSYS project is typically setup by connecting components graphically in the Simulation Studio. Each Type of component is described by a mathematical model in the TRNSYS simulation engine and has a set of matching Proforma's in the simulation studio. The proforma has a black-box description of a component: inputs, outputs, parameters, etc. The connections created between the components in the simulation studio act as paths of information flow between coupled components. The outputs of the first component are configured to be the inputs of the second component [12]. The information flow diagram for the entire system is created as shown in Figure 1.

\section{Evacuated Tube Collector}

The collector was modeled using the standard evacuated tube collector model available in TRNSYS library (TYPE 71), as shown in Figure 1. This TYPE requires various inputs to model the collector efficiently such as collector area, number of collectors in series, fluid specific heat, tested flow rate of the collector, intercept efficiency, etc. The collector specifications are mentioned in Table 1 . The collector efficiency can be evaluated using the below equation

$$
\eta=\eta_{0}-C_{1}\left(\frac{t_{m}-t_{a}}{G}\right) C_{2}\left(\frac{t_{m}-t_{a}}{G}\right)^{2}
$$

where,

$\eta$ is the collector efficiency. 


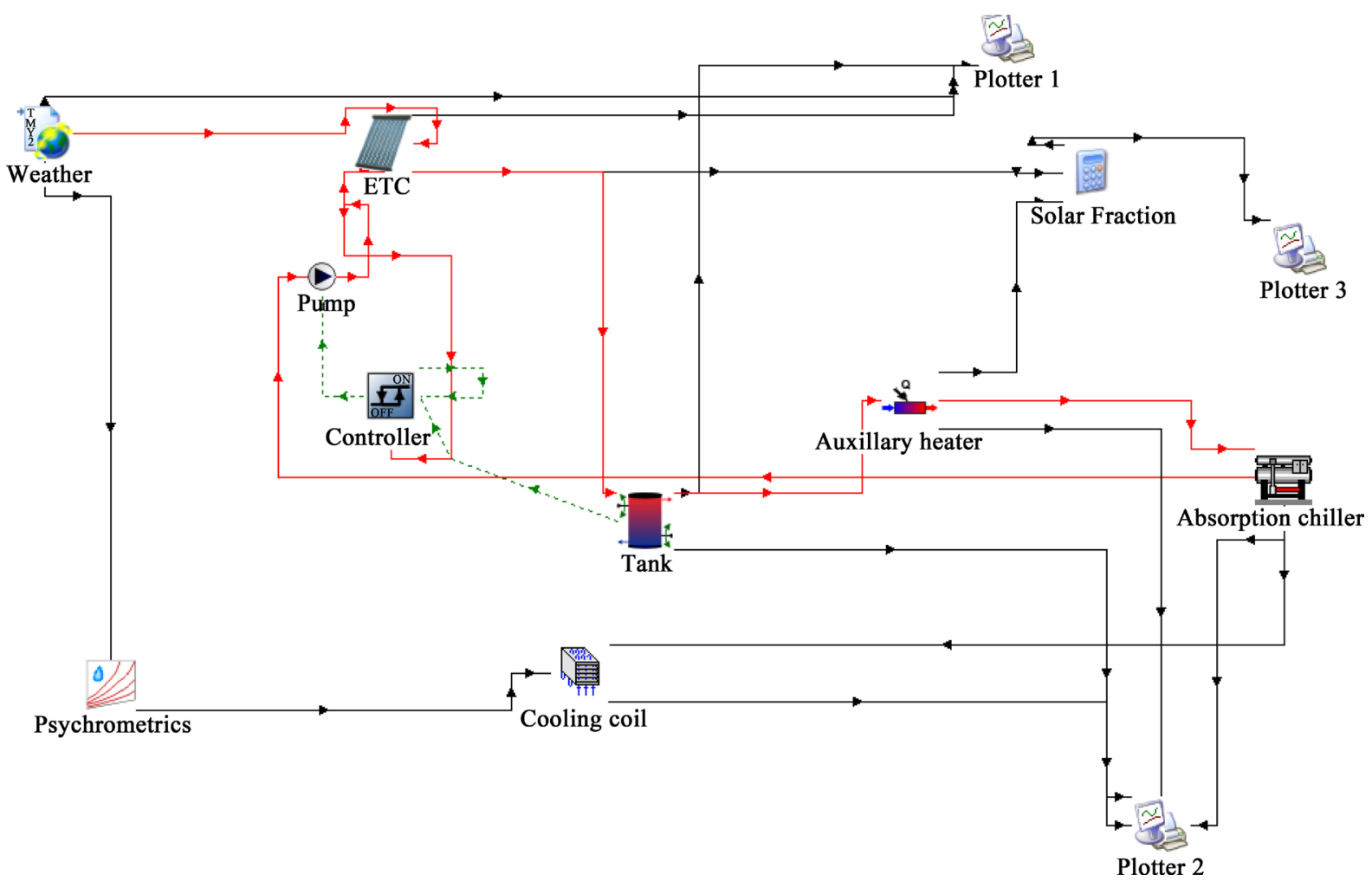

Figure 1. TRNSYS layout of solar air conditioning system.

Table 1. Input parameters for collector model.

\begin{tabular}{ccc}
\hline Name & Value & Unit \\
\hline Number in series & 8 & - \\
Collector area & 35 & $\mathrm{~m}^{2}$ \\
Fluid specific heat & 4.19 & $\mathrm{~kJ} / \mathrm{kg} \cdot \mathrm{K}$ \\
Efficiency mode & 1 & - \\
Tested flow rate & 40 & $\mathrm{~kg} / \mathrm{hr}^{2}$ \\
Intercept efficiency & 0.75 & - \\
Efficiency slope & 6.15 & $\mathrm{~W} / \mathrm{m}^{2} \cdot \mathrm{K}$ \\
Efficiency curvature & 0.03 & $\mathrm{~W} / \mathrm{m}^{2} \cdot \mathrm{K}^{2}$ \\
\hline
\end{tabular}

$\eta_{0}$ is the optical efficiency.

$C_{1}$ is collector's first order loss coefficient which is provided by the manufacturer.

$\mathrm{C}_{2}$ is collector second order loss coefficient which can be provided by manufacturer.

$t_{m}$ is the collector temperature.

$t_{a}$ is the ambient temperature.

$G$ is solar radiation in the collector plane.

\section{Weather data reading and processing}

For a successful simulation, accurate weather data for calculation of the incident radiation energy on the collector surface is necessary. For this purpose, a user defined weather file (Type 109 TMY2) is used to obtain the solar irradiance and various weather conditions for Gandhinagar.

Absorption chiller

The TRNSYS inbuilt Type 107 for modelling single-effect absorption chillers uses an external absorption chiller performance data file for predicting the chiller performance at the prevailing conditions of hot water supply, cooling water and chilled water inlet temperature. A 30 TR absorption chiller was modelled for which the 
datasheet was acquired from the manufacturer YAZAKISC30. These parameters can be found in Table 2. The Coefficient of Performance (COP) of the absorption chiller is calculated as follows:

$$
C O P_{a b s}=\frac{Q_{c h w}}{Q_{a u x}+Q_{h w}+Q_{p}}
$$

where,

$C O P_{a b s}$ is absorption chiller coefficient of performance.

$Q_{c h w}$ is energy removed from chilled water stream.

$Q_{a u x}$ is energy drawn from the auxiliary heater.

$Q_{h w}$ is energy removed from hot water stream.

$Q_{p}$ is energy drawn by pumps.

\section{Storage Tank}

Type 4a is used to model the storage tank. This type can be used to model storage tanks with fixed inlets and uniform losses. The system also had an auxiliary heater responsible for providing minimum water outlet temperature $\left(80^{\circ} \mathrm{C}\right.$ in the present work) to the chiller system. In order to prevent boiling of water inside the tank, the hot water outlet temperature was set as $98^{\circ} \mathrm{C}$ as an upper limit.

\section{Control Strategy}

Differential Controllers (TYPE 2b) are employed to simulate real time conditions. The function of the controller (on-off) is to manage the flow through the collector depending on the fluid temperature difference across the collector array. Once the temperature of the collector exceeds the temperature at the bottom of the storage tank by $5-10 \mathrm{~K}$, the collector pump is turned ON. On the other hand, if the temperature at the collector output is lower than that of the input by $2 \mathrm{~K}$, the pump is turned OFF [13]. Therefore, the condition at which the collector loop pump works is:

1) Temperature of inlet water to the collector is lower than temperature of outlet water of collector (T collector out $>\mathrm{T}$ collector in) and

2) Temperature of the outlet water of collector is less than $98^{\circ} \mathrm{C}$.

\subsection{Parametric Analysis}

There are various parameters that affect the performance of the simulated solar absorption system. The factors that were investigated in this simulation are storage tank volume, collector slope, collector area, the mass flow rate through the collectors, useful energy gain and auxiliary energy consumption. The simulation was carried out for the entire year.

\section{Effect of collector slope}

The effect of the collector tilt angle for a south facing collector was investigated. In theory, the optimum value of collector slope for a non-tracking collector should be the latitude of the location of the collector. The collector slope was varied in the range of $3^{\circ}$ to $35^{\circ}$ as shown in Figure 2. The results indicated that the highest

Table 2. Parameters for YAZAKI 30 ton Chiller.

\begin{tabular}{ccc} 
& \multicolumn{1}{c}{ Chiller Model: YAZAKI WFC-SC30 } \\
\hline & Cooling capacity & $105.6 \mathrm{KW}$ \\
\hline Chilled water & Inlet temperature & $12.5^{\circ} \mathrm{C}$ \\
& Outlet temperature & $7{ }^{\circ} \mathrm{C}$ \\
Rooling water & Rated flow rate & $16.5 \mathrm{~m}^{3} / \mathrm{hr}$ \\
& Inlet temperature & $31^{\circ} \mathrm{C}$ \\
& Outlet temperature & $35^{\circ} \mathrm{C}$ \\
Hot water & Rated flow rate & $55.1 \mathrm{~m}^{3} / \mathrm{hr}$ \\
& Inlet temperature & $88^{\circ} \mathrm{C}$ \\
& Outlet temperature & $83^{\circ} \mathrm{C}$ \\
& Inlet temperature range & $70^{\circ} \mathrm{C}-95^{\circ} \mathrm{C}$ \\
& Rated flow rate & $25.9 \mathrm{~m}^{3} / \mathrm{hr}$ \\
\hline
\end{tabular}




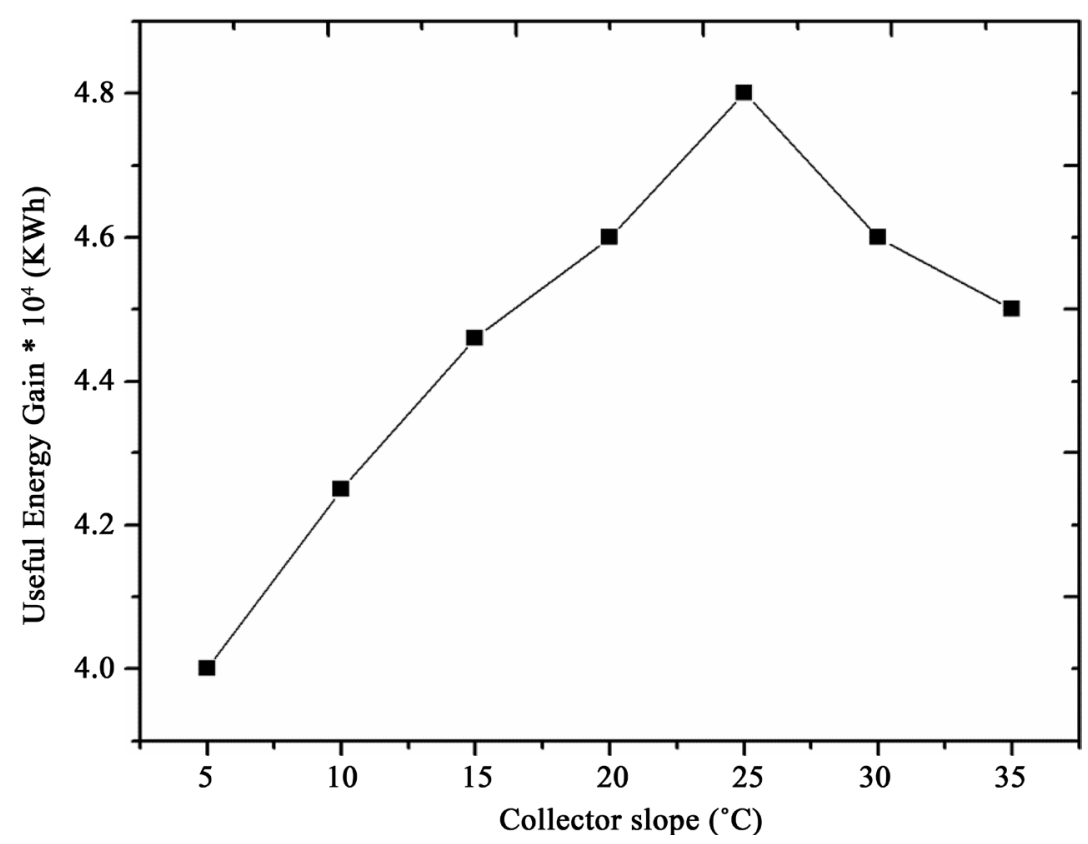

Figure 2. Collector slope vs useful energy gain.

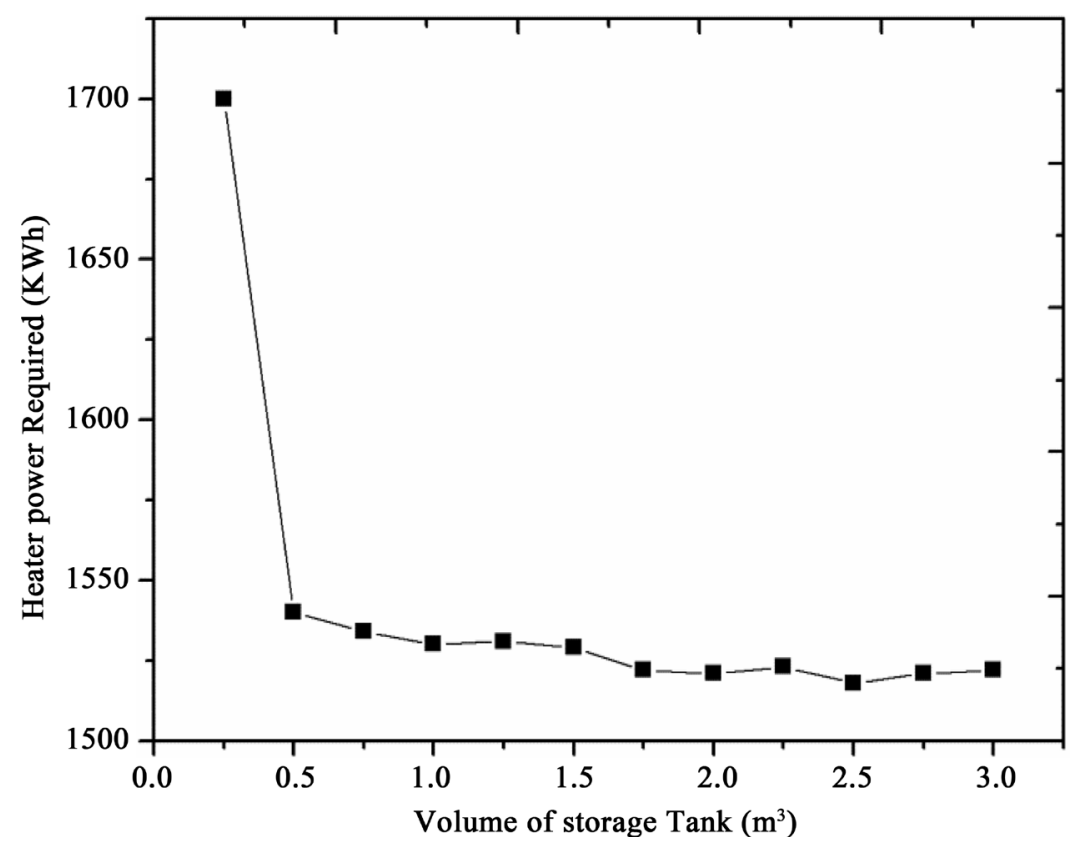

Figure 3. Annual heater power required vs volume of storage tank.

collector energy gain is when the slope angle is equal to the local latitude. Hence, the optimum collector slope is $24^{\circ} \mathrm{N}$, which is close to the latitude of Gandhinagar $24.22^{\circ} \mathrm{N}$.

\section{Effect of storage tank volume}

The optimum storage tank is determined by examining the influence of storage volume on the system performance. For this purpose, the storage tank volume is varied from $0 \mathrm{~m}^{3}$ to $3 \mathrm{~m}^{3}$. An optimum value of storage tank would be at which minima is achieved in the trend of annual auxiliary heater power required over the parametric analysis of storage tank volume. This result was confirmed by observing the trend in Figure 3.

Since at the optimum storage tank volume, minima can be seen in the trend of auxiliary heater power required and useful solar energy being inversely proportional, maxima should be seen in its trend. The same is observed 
in Figure 4 which shows the trend of annual useful solar energy during different storage tank volume iterations.

The solar fraction computes the fraction of thermal energy delivered to the absorption chiller generator that comes from solar energy. In order to achieve a high solar fraction, auxiliary heater energy should be reduced.

$$
\text { Solar fraction }=\frac{\text { useful solar energy }}{\text { Generator load }}
$$

An optimum storage tank volume would be the one that achieves the highest solar fraction. It was observed from Figure 5 that a storage tank volume of $0.5 \mathrm{~m}^{3}$ provided the maximum solar fraction.

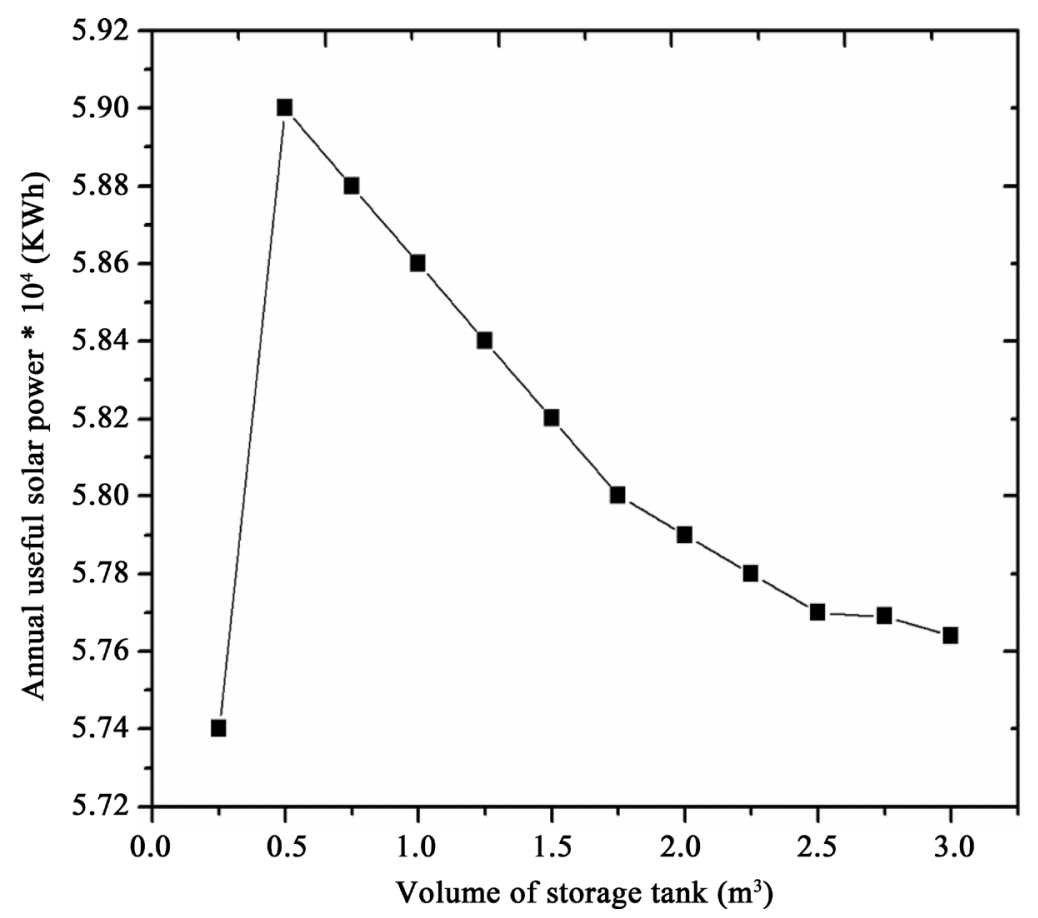

Figure 4. Annual useful solar power vs volume of storage tank.

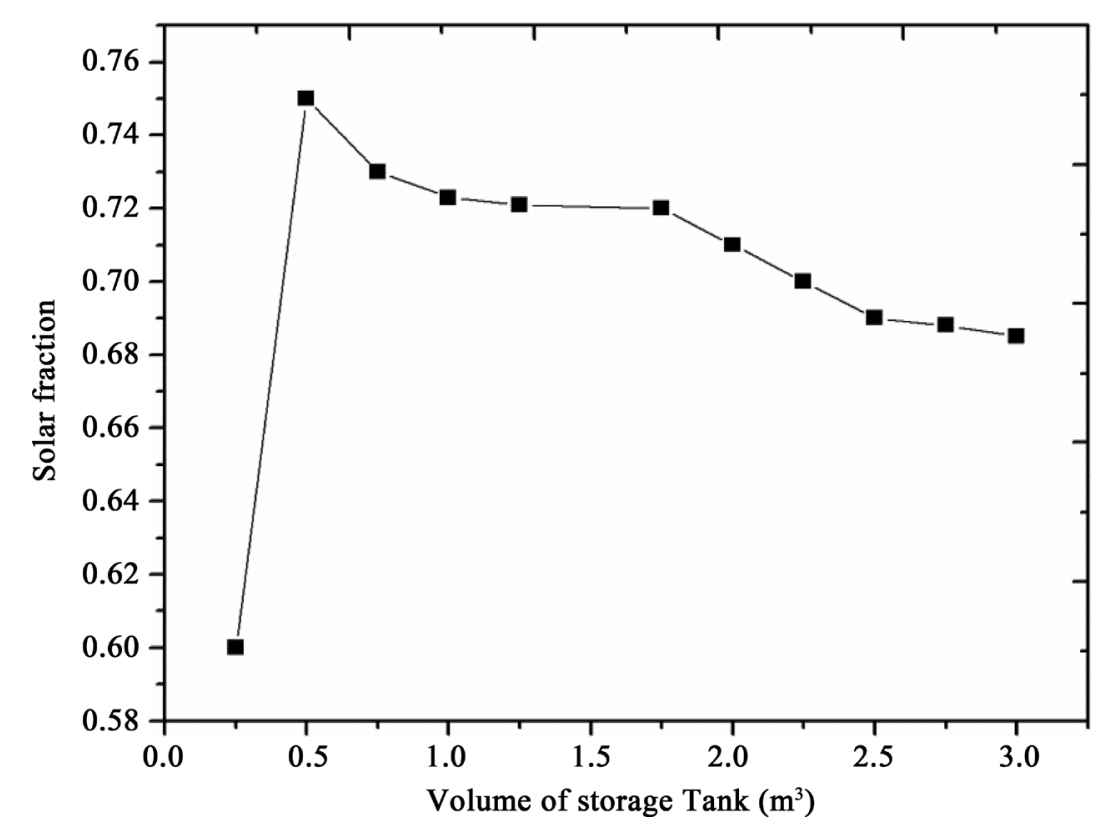

Figure 5. Solar fraction vs volume of storage tank. 
From the above graphs, we can conclude that the optimum storage tank volume is $0.5 \mathrm{~m}^{3}$.

\section{Effect of collector area}

The specific collector area was changed from 0 to $80 \mathrm{~m}^{2}$. Figure 6 shows the variation of the annual solar fraction and varying collector area. It was observed that the solar fraction increased with increase in collector area, but the effect of increasing collector area is more significant only till $35 \mathrm{~m}^{2}$. After $35 \mathrm{~m}^{2}$ collector area, the slope of increase of annual solar fraction decreases with increasing collector area. A similar trend is noted for useful solar power, as observed in Figure 7.

It can be observed from Figure 8 as expected that auxiliary heater power required shows an opposite trend to that of the useful power and solar fraction. Heater power required decreases with increase in collector area till 35 $\mathrm{m}^{2}$, and then the slope is almost linear. On the other hand, useful collector heat increases with increase in

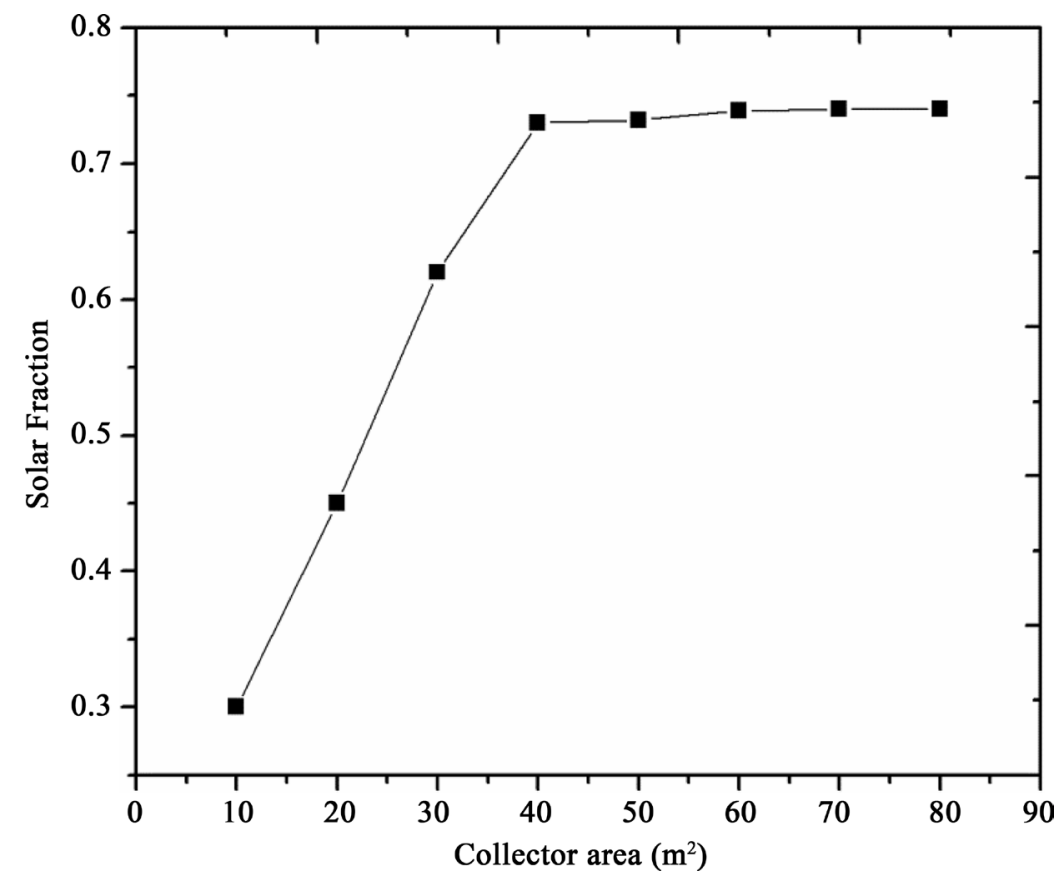

Figure 6. Solar fraction vs collector area.

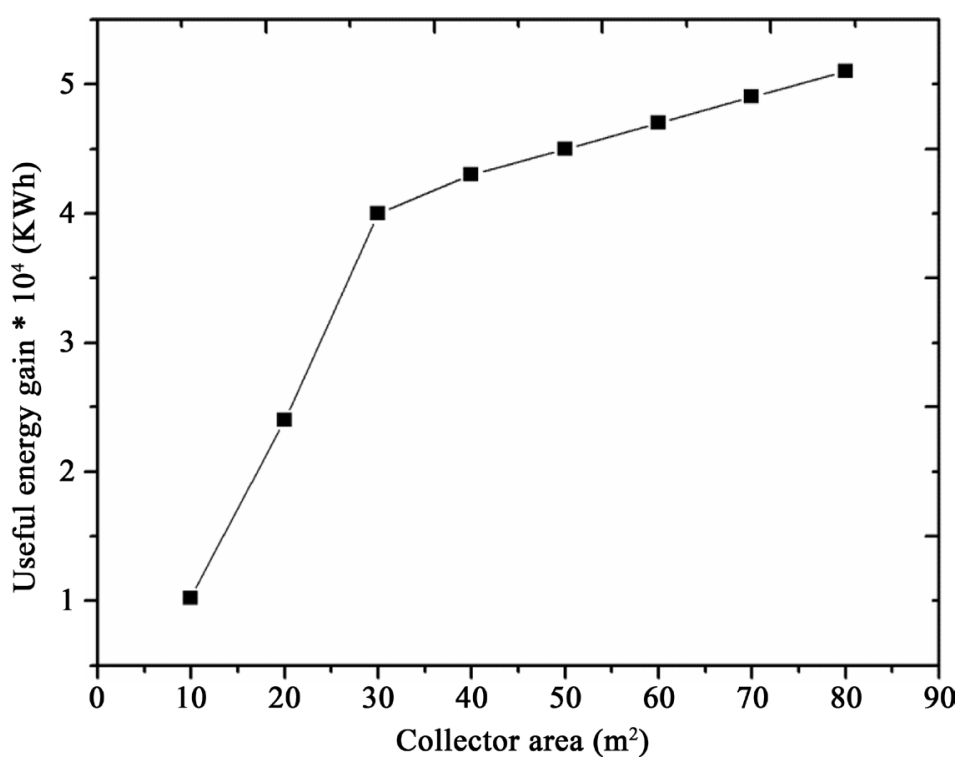

Figure 7. Useful energy gain vs collector area. 
collector area as shown in Figure 7.

The parametric analysis based on collector area could not provide an optimum value. The optimum value would be close to $35 \mathrm{~m}^{2}$ collector area as this is where the gradient of increase in solar fraction and decrease in useful solar power is observed. Thermo economic analysis is required for optimizing the solar collector area.

\section{Effect of mass flow rate}

The effect of varying the mass flow rate through the collector array is investigated. It can be observed from Figure 9 that collector mass flow rate of $1000 \mathrm{~kg} / \mathrm{h}$ maximizes the solar fraction up to 0.75 . Therefore, it is regarded as the optimum value. However, it is important to mention that a variation in the water flow rate from

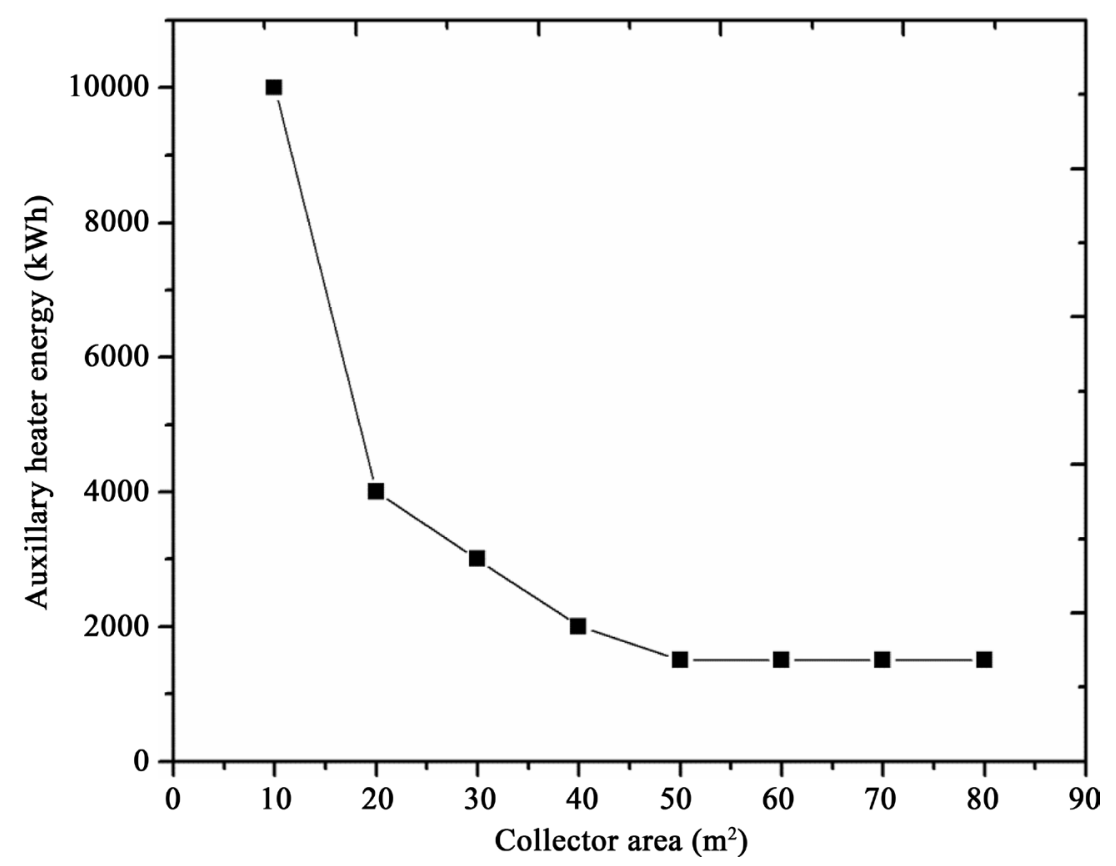

Figure 8. Heater power required vs collector slope.

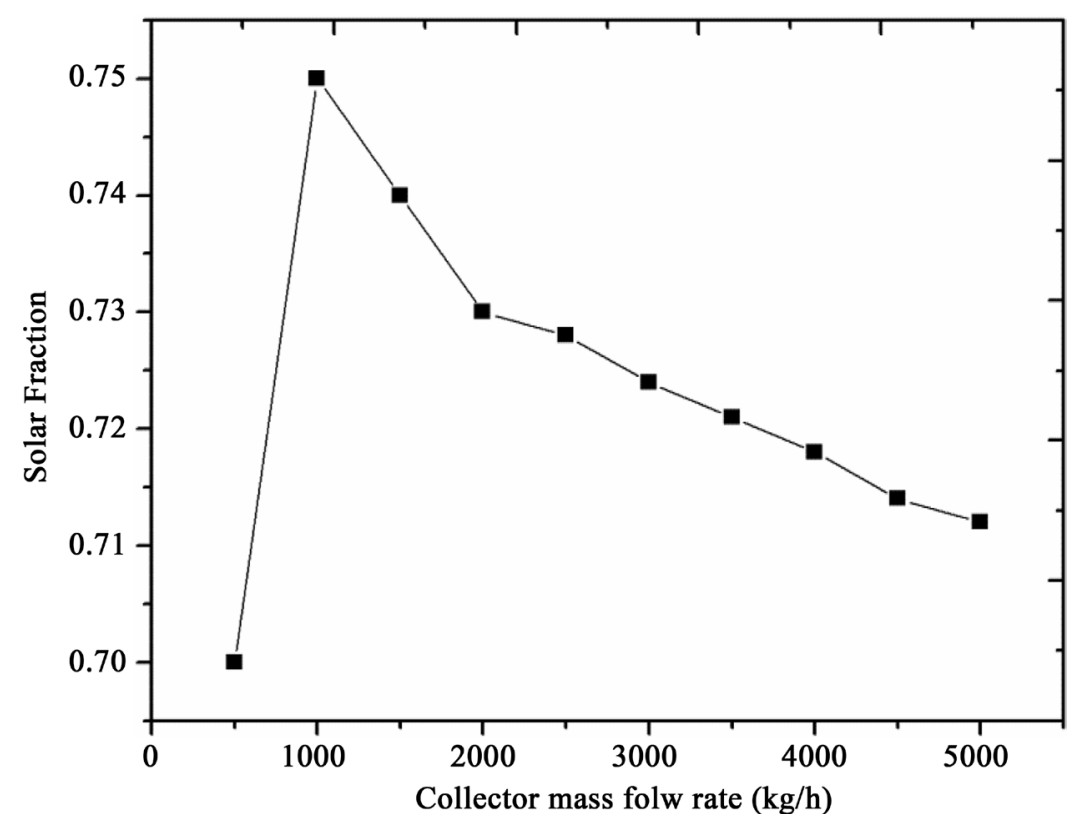

Figure 9. Solar fraction vs collector mass flow rate. 
300 to $10,000 \mathrm{~kg} / \mathrm{h}$ did not represent a big variation in the yearly solar fraction that was in the range of 0.70 to 0.74 .

The final system specifications based on the optimization study is shown in Table 3.

\section{Results and Discussions}

The simulation is performed for the entire year (Jan to Dec), i.e., 8760 hours with a simulation time step of $0.125 \mathrm{hr}$. The first parameter that was taken into consideration was collector outlet temperature.

In the beginning, the system takes some time to warm up. Hence, the curve is flat as can be seen from the bottom left side of Figure 10. At around 10:00 am, when the intensity of radiation is high, around $50^{\circ} \mathrm{C}$ was obtained. Whereas during the peak solar time, i.e., 13:00 a.m., a maximum temperature of around $180^{\circ} \mathrm{C}$ was delivered that could be stored in the storage tank. During the evening period after 20:00 a.m. there is again a linear trend seen in the figure till 30.75 hours (6:00 a.m.) the next day. The trend is due to the drop in the radiation levels in the evening time which contributes to the linear trend. Another observation is that the system collected energy efficiently for a period of nine hours that is from about 10 a.m. to 7 p.m.

It is evident from Figure 10 that a constant outlet temperature of more than $160^{\circ} \mathrm{C}$ is obtained from ETC throughout the year indicating a stable operation. Peak temperatures of around $230^{\circ} \mathrm{C}$ are obtained from the collector during 2191 - 4300 hours (March-July) during which the radiation levels are maximum in the region of Gandhinagar. Moreover, a similar trend in the form of the peak is seen for different days of the month from 10:00 am to 20:00 pm. Similarly, a linear trend is seen in the night and early morning.

As seen in Figure 11, the outlet temperature obtained from the storage tank is $99^{\circ} \mathrm{C}$, which is favourable as

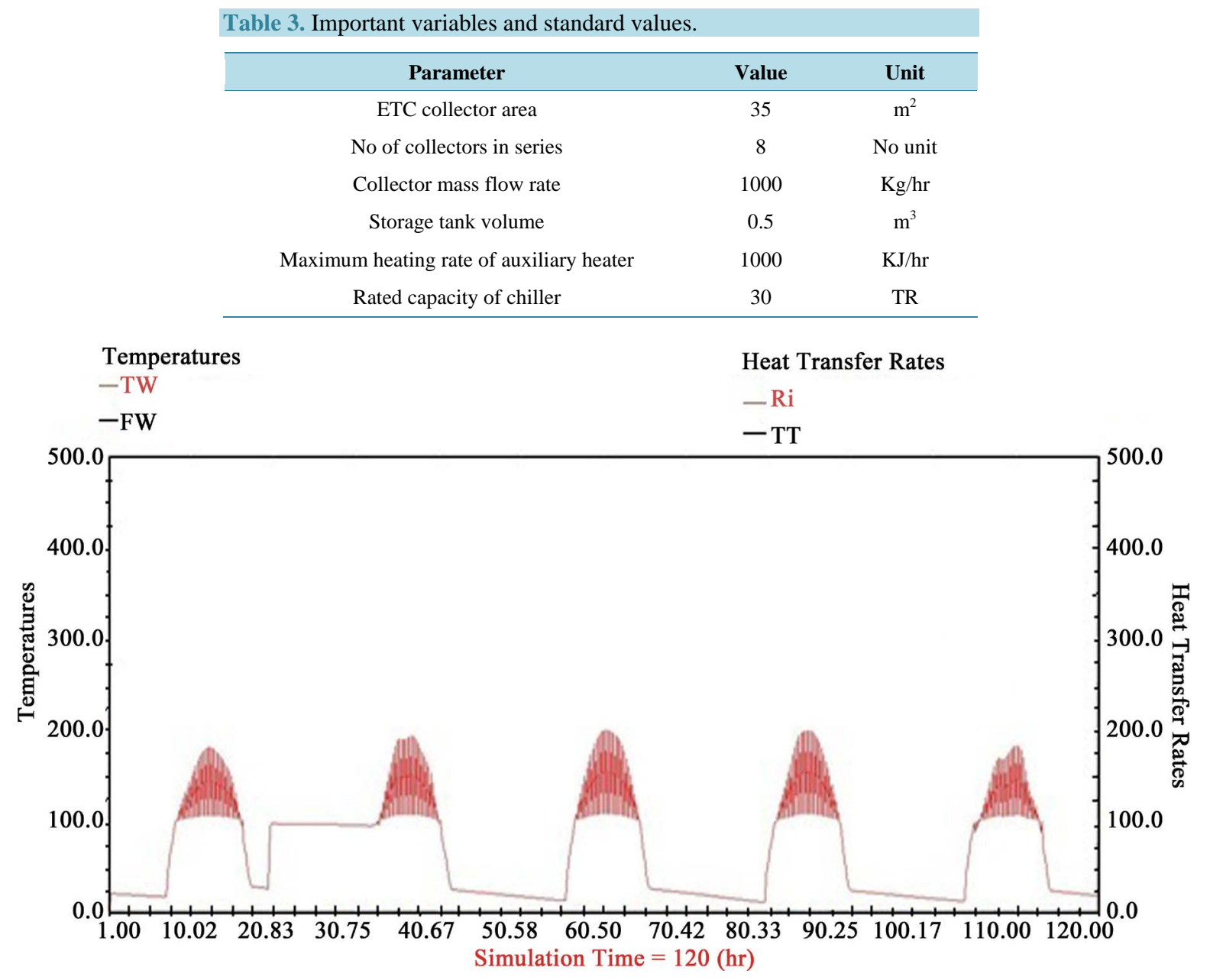

Figure 10. Plot of collector outlet temperature. 

Temperatures
-Chilled
- Hot
Heat Transfer Rates
-Fluid

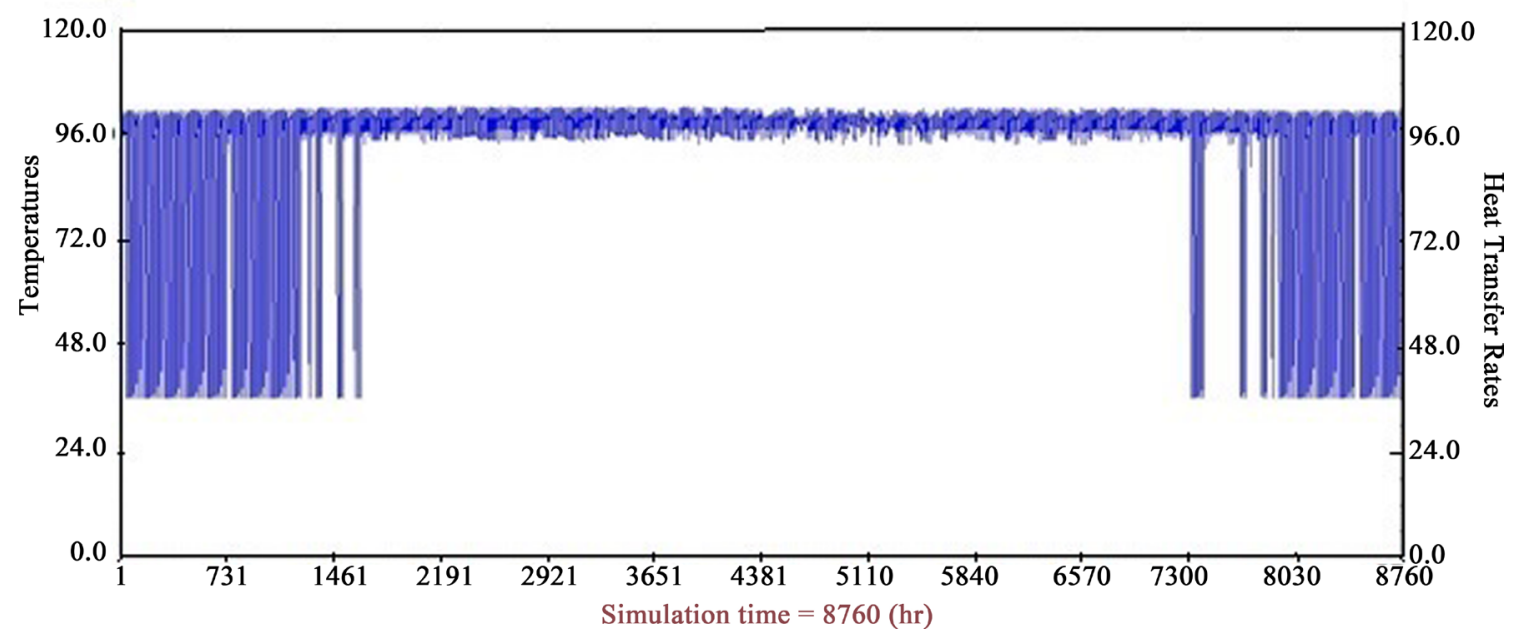

Figure 11. Plot of storage tank outlet temperature.

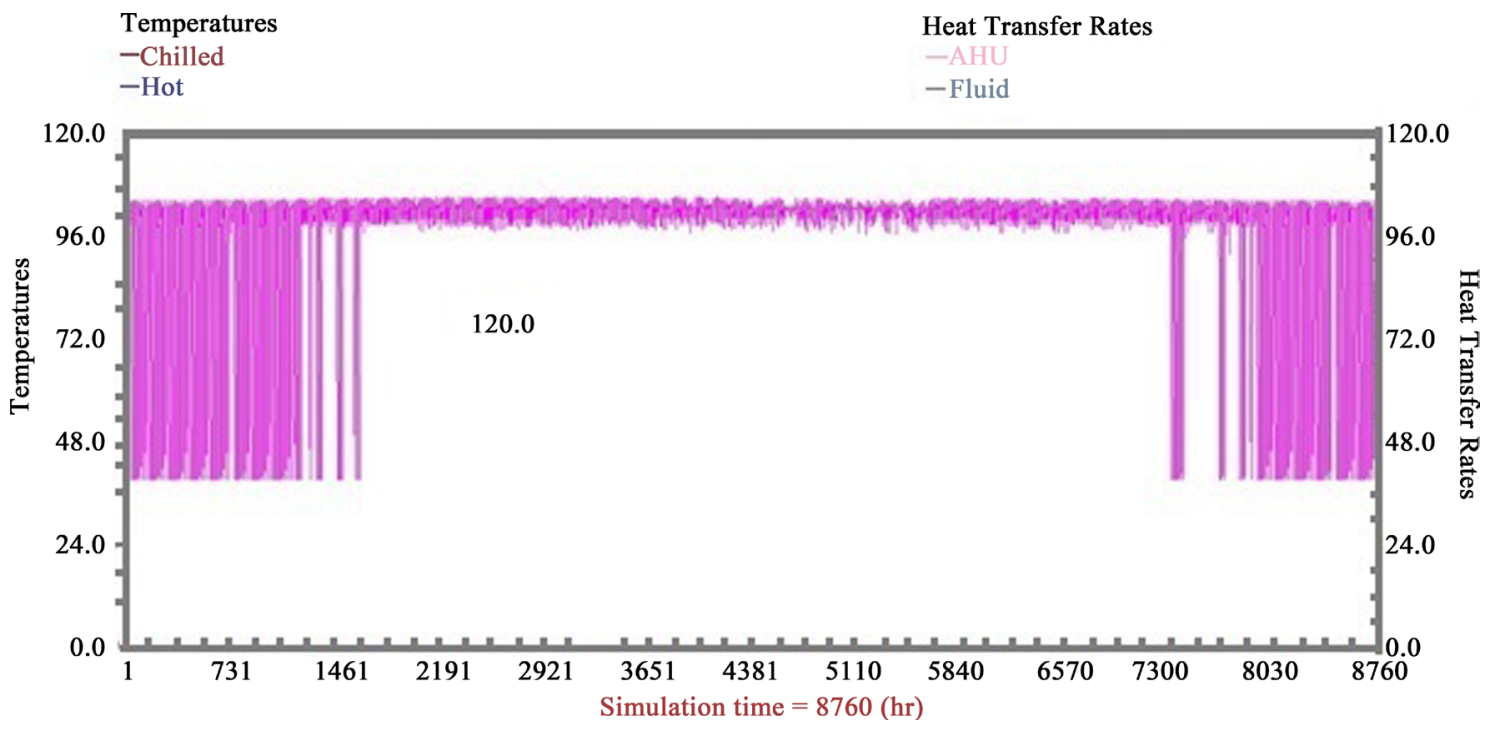

Figure 12. Plot of auxiliary heater outlet temperature.

the system is working on atmospheric conditions. The outlet temperature of the collector should be below $100^{\circ} \mathrm{C}$ in all cases. Hence the storage tank volume of $0.5 \mathrm{~m}^{3}$ can provide a constant temperature. The fluctuating yellow lines are noticeable during the periods of $0-1500$ and 7300 - 8760 hours that corresponds to the months of January-March and October-December. These are the times that are considered to be the cooling periods. The solar radiation will be less intense during these periods. As the radiation is directly proportional to the tank outlet temperature, the tank outlet temperature will be less during these periods thereby the reason for fluctuations. The observation of linear trend was during the hottest periods.

A similar trend is noticeable for auxiliary heater temperature which is shown in Figure 12. Auxiliary heater only supplies energy when the storage tank is not sufficiently charged, i.e., cannot supply hot water at a minimum temperature of $100^{\circ} \mathrm{C}$.

The next important parameter is the chilled water outlet temperature. The hot water from the storage tank goes to the absorption chiller generator and comes out as chilled water. The chiller remains in operation as long as there is hot water and a demand for chilled water. It is noticeable from Figure 13 that a constant chilled water temperature of $6.6^{\circ} \mathrm{C}$ is obtained throughout the year. 


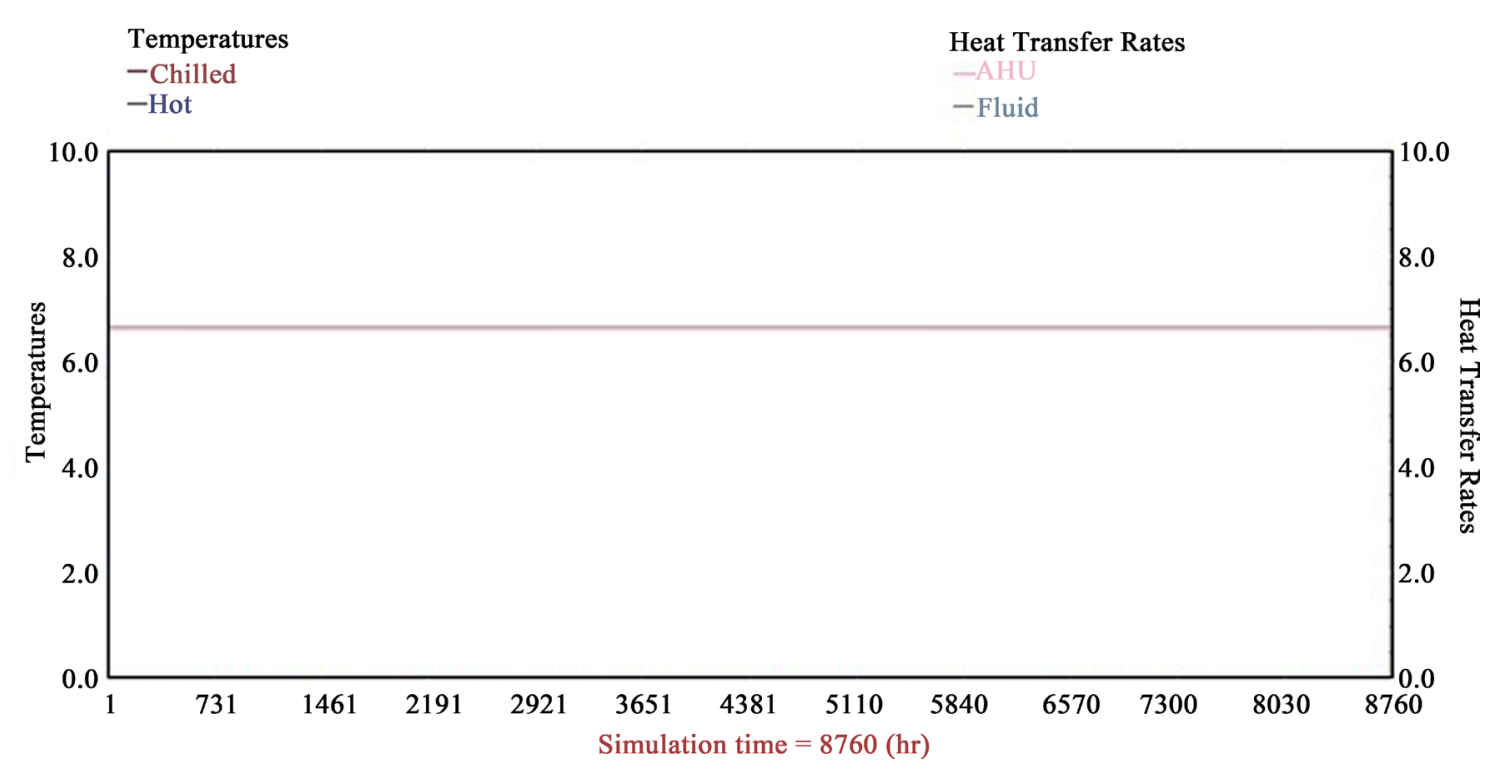

Figure 13. Plot of chiller water outlet temperature.

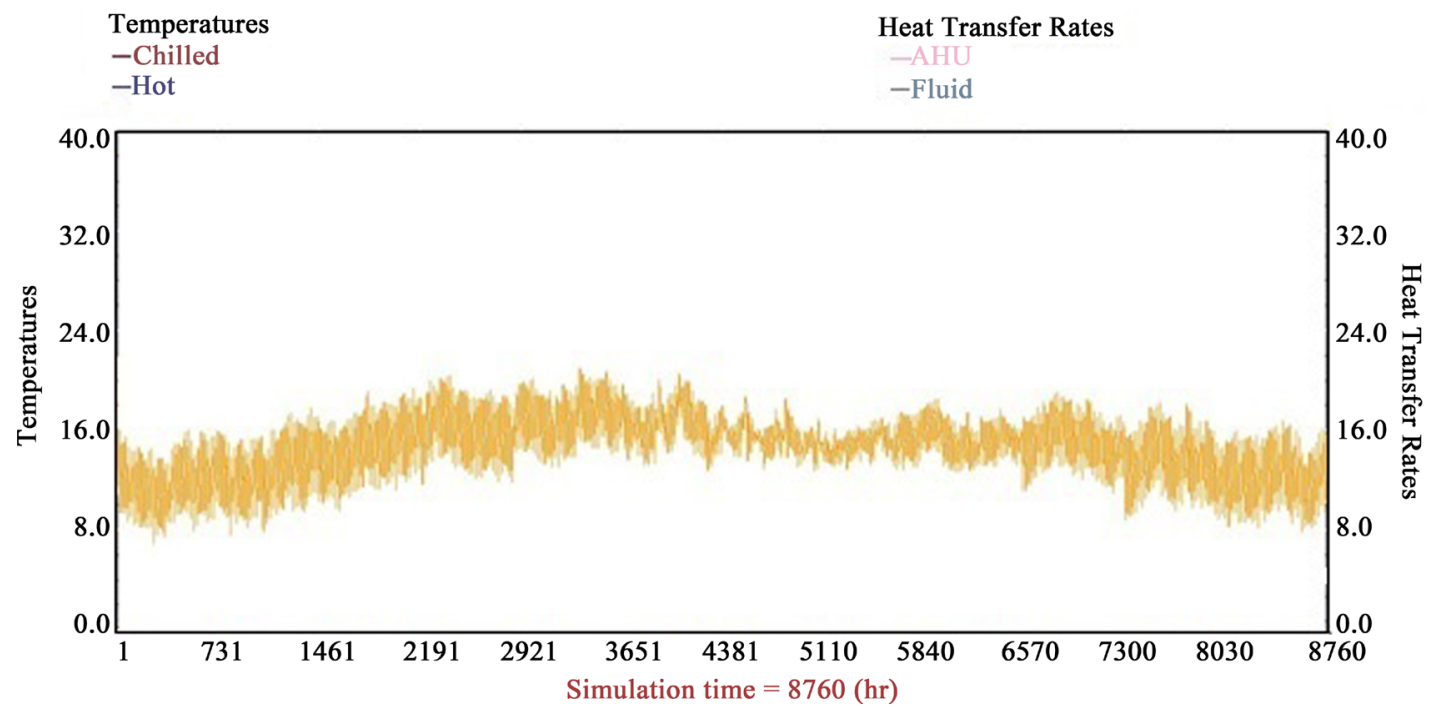

Figure 14. Temperature variations inside the building.

The chilled water interacts in the cooling coil with air and removes the heat from the building via an air handling unit. Figure 14 indicates the temperature maintained in the building. It can be observed in that with the help of solar air conditioning system even during the peak summer months a temperature of close to $22^{\circ} \mathrm{C}$ is maintained which leads to thermal comfort. The main purpose of this air conditioning is the thermal comfort that is usually in the range of $18^{\circ} \mathrm{C}-22^{\circ} \mathrm{C}$. The proposed solar air conditioning system maintains a temperature in the range of $16^{\circ} \mathrm{C}-22^{\circ} \mathrm{C}$, which satisfies the cooling demand.

The solar fraction (Figure 15) computes the fraction of thermal energy delivered to the absorption chiller generator that comes from solar energy. Higher the solar fraction more efficient is the system. The proposed solar air conditioning system can achieve an average solar fraction of 0.75 which is quite high.

Financial analysis

The cost for design, supply, installation and commissioning of solar hot water fired 30 TR single effect vapor absorption chiller = Rs. 20,62,857 (Manufacturer Quotation).

Operation and Maintenance cost $=$ Rs. 10, 00,000.

MNRE Subsidy = Rs. 9, 18,857 (30\% of capital cost). 


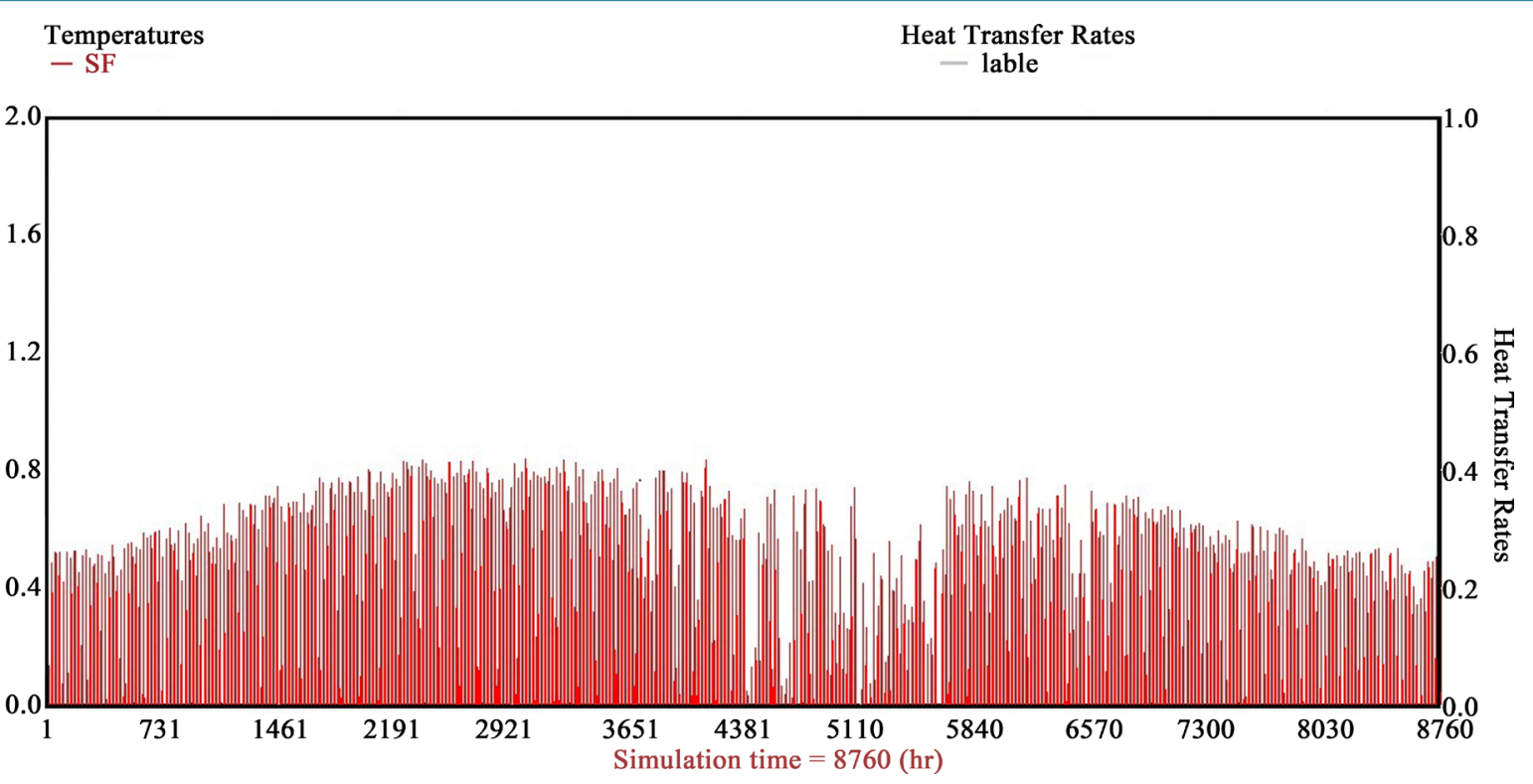

Figure 15. Plot of solar fraction.

Net cost $=$ Rs. 30, 62,857 - Rs.9, 18,857 = Rs. 21, 44,000.

Number of sunny days in Gandhinagar $=300$.

Number of working days of office $=270$.

Working Hours per day $=9$ hours.

Energy saving per annum $=105.5 \times 270=28,485 \mathrm{kWh}$.

Cost of electricity per unit (2015) $=$ Rs. 9 .

Savings in energy bill per year $=28,485 \times 8=$ Rs. 2, 27,880.

Simple payback period $=\frac{\text { Rs.21, 44,000 }}{\text { Rs.1,99,395 }}=9$ years.

This payback period doesn't include accelerated depreciation benefit and fuel escalation price.

\section{Conclusions}

Transient modeling of a solar-powered absorption system was carried out using TRNSYS with the collector model input parameters taken from the measured performance data of an ETC. A sensitivity analysis was also presented, determining the approximate optimum values of a few design and operational parameters. The results obtained from the parametric optimization of the simulated solar-based absorption system indicate that an area of $35 \mathrm{~m}^{2}$ of evacuated tube collectors with an inclination of $24.2^{\circ}$ and $0.5 \mathrm{~m}^{3}$ of storage tank can satisfy the cooling demand of an office building of $1000 \mathrm{~m}^{2}$ located in Gandhinagar.

Therefore, it becomes evident that the validated TRNSYS simulated model, in conjunction with Gandhinagar weather data, can be used as a useful engineering design tool to predict the long-term performance of a solar cooling system without actually performing expensive prototype or full scale testing.

Future developments of this work will include the development of a complete cost model to be installed in the office building for experimental analyses and model validation under actual climatic conditions.

\section{References}

[1] Planning Commission (2011) Low Carbon Strategies for Inclusive Growth: An Interim Report. Planning Commission, Government of India, New Delhi.

[2] Duffie, J.A. and Beckman, W.A. (1991) Solar Engineering of Thermal Processes. Wiley, Hoboken.

[3] Assilzadeh, F., Kalogirou, S.A., Ali, Y., et al. (2005) Simulation and Optimization of aLiBr Solar Absorption Cooling System with Evacuated Tube Collectors. Renewable Energy, 30, 1143-1159.

[4] Florides, G.A., Kalogirou, S.A., Tassou, S.A., et al. (2002) Modeling and Simulation of Anabsorption Solar Cooling 
System for Cyprus. Solar Energy, 72, 43-51.

[5] Lokurlu, A. and Muller, G. (2005) Experiences with the Worldwide First Solar Cooling System Based on Trough Collectors Combined with Double Effect Absorption Chillers. Proceedings of the International Conference on Solar AirConditioning, Bad Staffelstein. http://www.scirp.org/journal/PaperInformation.aspx?PaperID=47541

[6] Martinez, P.J., Gracia, A. and Pinazo, J.M. (2003) Performance Analysis of an Air Conditioning System Driven by Natural Gas. Energy Build, 35, 669-674.

[7] Ayompe, L.M., Duffy, A., McCormack, S.J., et al. (2011) Validated TRNSYS Model for Forced Circulation Solar Water Heating Systems with Flat Plate and Heat Pipe Evacuated Tube Collectors. Applied Thermal Engineering, 31, 1536-1542.

[8] Eicker, U. and Pietruschka, D. (2009) Design and Performance of Solar Powered Absorption Cooling Systems in Office Buildings. Energy and Buildings, 41, 81-91.

[9] Zambrano, D., Bordons, C., Garcia-Gabin, W. and Camacho, E.F. (2008) Model Development and Validation of a Solar Cooling Plant. International Journal of Refrigeration, 31, 315-327.

[10] Mittal, V., Kasana, K.S. and Thakur, N.S. (2005) Harnessing Solar Energy for Absorption Air-Conditioning System. Proceedings of International Congress on Renewable Energy Resources, Pune, 20-22 January 2005, 115-127.

[11] ASHRAE (American Society of Heating, Refrigerating and Air-Conditioning Engineers), Inc. (2004) ASHREA Handbook: Heating, Ventilating, and Air-Conditioning Systems and Equipments. ASHRAE, Atlanta, 36.13-36.20.

[12] TRNSYS (2004) A Transient System Simulation Program. Version 16. University of Wisconsin, Madison. http://sel.me.wisc.edu/trnsys/

[13] Goswami, Y., et al. (2000) Principles of Solar Engineering. Taylor and Francis, London.

\section{Submit or recommend next manuscript to SCIRP and we will provide best service for you:}

Accepting pre-submission inquiries through Email, Facebook, LinkedIn, Twitter, etc.

A wide selection of journals (inclusive of 9 subjects, more than 200 journals)

Providing 24-hour high-quality service

User-friendly online submission system

Fair and swift peer-review system

Efficient typesetting and proofreading procedure

Display of the result of downloads and visits, as well as the number of cited articles

Maximum dissemination of your research work

Submit your manuscript at: http://papersubmission.scirp.org/ 